\title{
Initiation of petroleum exploration in Jameson Land, East Greenland
}

\author{
Finn Surlyk, Stefan Piasecki and Flemming Rolle
}

\begin{abstract}
Active petroleum exploration in East Greenland is of fairly recent date and was preceded by a much longer history of scientific work and mineral exploration. The discovery in 1948 of lead-zinc mineralisation at Mestersvig resulted in the formation of Nordisk Mineselskab A/S in 1952. In the beginning of the seventies Nordisk Mineselskab initiated cooperation with the American oil company Atlantic Richfield (ARCO) in order to undertake petroleum exploration in Jameson Land.

The Jameson Land basin contains a very thick Upper Palaeozoic - Mesozoic sedimentary sequence. Important potential source rocks are Lower Permian lacustrine mudstone, Upper Permian black marine mudstone, Middle Triassic dark marine limestone, uppermost Triassic black marginal marine mudstone, Lower Jurassic black mudstone and Upper Jurassic deep shelf black mudstone. The Upper Permian mudstone, which is the most promising source rock, is immature to weakly mature along the western basin margin and is expected to be in the oil or gas-generating zone when deeply buried in the central part of the basin.

Potential reservoir rocks include Upper Permian bank and mound limestones, uppermost Permian fan delta sandstones, Lower Triassic aeolian and braided river sandstones, and Lower, Middle and Upper Jurassic sandstones.

The most important trap types are expected to be stratigraphic, such as Upper Permian limestone bodies, or combination stratigraphic-structural such as uppermost Permian or Lower Triassic sandstones in Early Triassic tilted fault blocks.

In the offshore areas additional play types are probably to be found in tilted Jurassic fault blocks containing thick Lower, Middle and Upper Jurassic sandstones and lowermost Cretaceous sandstones and conglomerates.

The recognition of the potential of the Upper Permian in petroleum exploration in East Greenland has important implications for petroleum exploration on the Norwegian shelf.
\end{abstract}

\section{Introduction}

Exploration for petroleum in the North Sea and around the margins of the NorwegianGreenland Sea was triggered by the discovery in 1959 of the super-giant gas field Groningen in the Netherlands. Over the next twenty years, more than fifty oil and gas fields were discovered in the U.K. sector, and a similar number in the Norwegian, Danish and Dutch sectors (fig. 1) (Brennand, 1984). At least as many small hydrocarbon accumulations have been found which may become economically viable in the future.

The first phase of offshore exploration in the late sixties was concentrated in the gas province of the southern North Sea. The discovery of the giant Ekofisk field in the Norwegian part of the North Sea in 1969 was a major turning point in the exploration for petroleum in western Europe. In the early seventies exploration moved northwards to concentrate on the Viking Graben area in the northern North Sea between Scotland and Norway. The discovery in this area of the giant Brent field in 1971 had a profound influence on exploration 


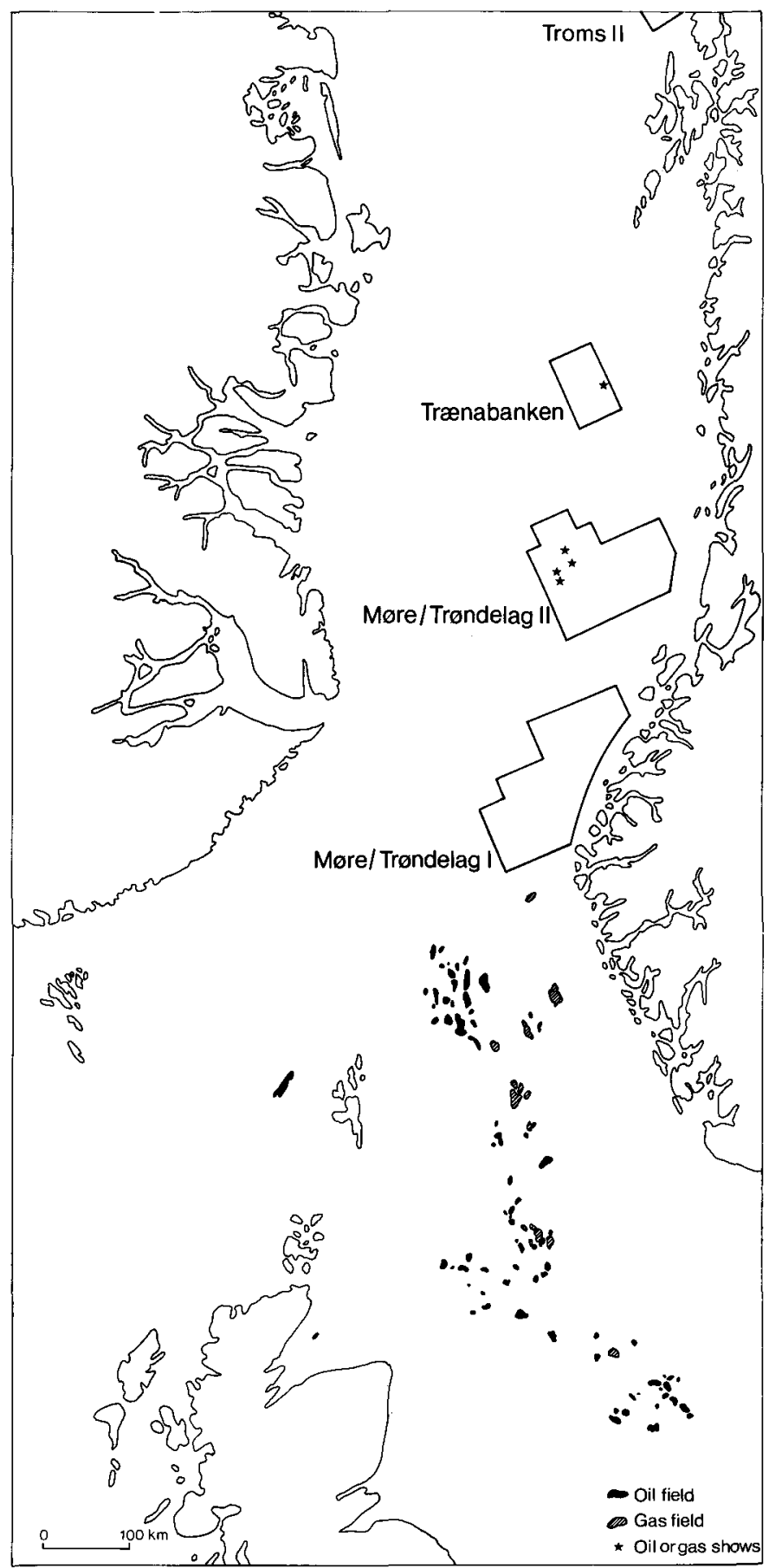

Fig. 1. Pre-drift map showing East Greenland, West Norway and the northern U.K. All known oil and gas fields and the four leased areas on the West Norwegian shelf are also indicated. Base map provided by H. C. Larsen (GGU). 
JAMESON LAND

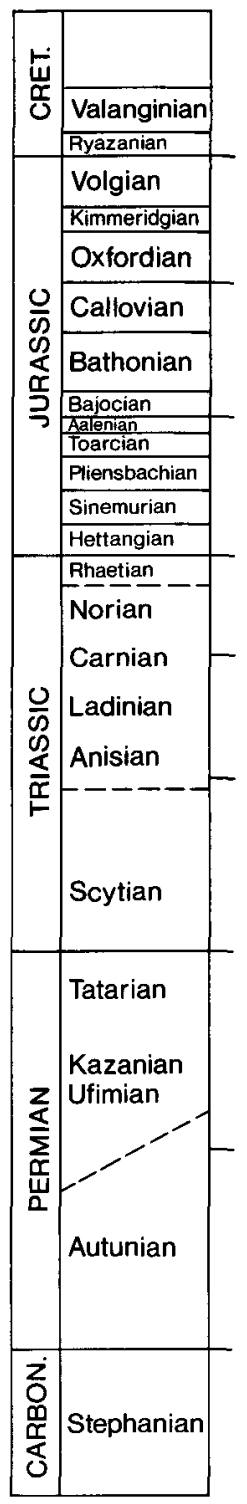

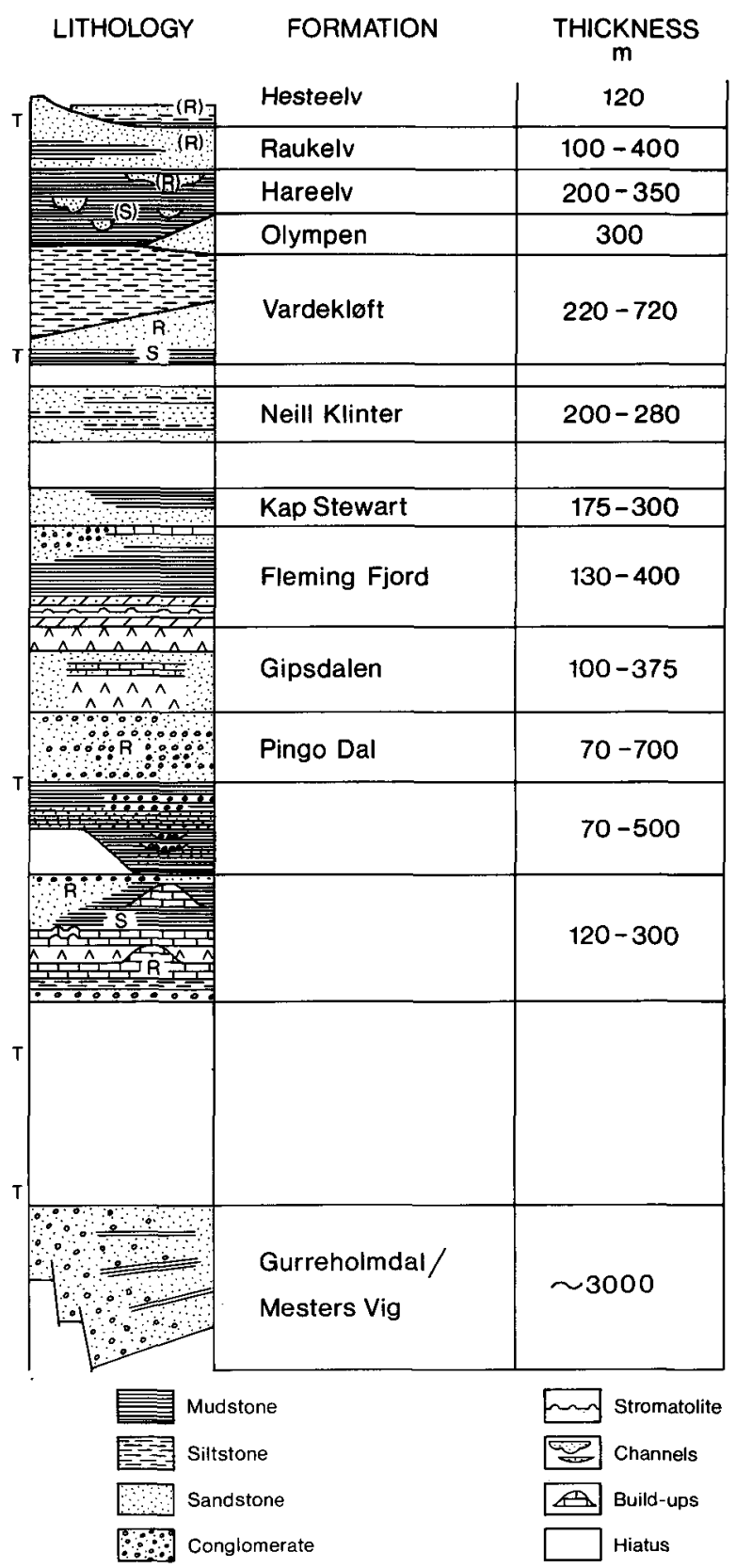

Fig. 2. Schematic stratigraphic section of the Upper Palaeozoic - Mesozoic sequence of Jameson Land. Main lithology and maximum thickness shown. $S$ indicates potential source rock, $R$ indicates potential reservoir and $\mathrm{T}$ indicates tectonic phase. 
and the subsequent four years witnessed a long series of discoveries in the northern North Sea (Brennand, 1984).

The main source and reservoir rocks of the northern North Sea are Upper Jurassic shale and Middle Jurassic sandstone respectively. The rapidly increasing information from drilling activity revealed that the offshore Jurassic sequence is quite different from the onshore $\mathrm{Ju}$ rassic of the British Isles. Only a few of the neighbouring areas could thus be used as analogues for the Viking Graben sequence and structural configuration.

Coincidentally, the Upper Palaeozoic - Mesozoic sequence exposed in Jameson Land and Scoresby Land, East Greenland, was mapped during GGU expeditions by geologists from the University of Copenhagen in the same period as oil exploration moved northwards in the North Sea. A coherent stratigraphic scheme (fig. 2) was produced for the Triassic - lowermost Cretaceous sequence (Surlyk et al., 1973; Perch-Nielsen et al., 1974; Clemmensen, 1980a), and was later extended to the island Milne Land (Callomon \& Birkelund, 1980, 1982; Birkelund et al., 1984) and the northern part of the East Greenland basin (Surlyk, 1977, $1978 \mathrm{a}, \mathrm{b})$.

It soon became clear that the Mesozoic basin of East Greenland is an almost perfect analogue of the Viking Graben. Virtually all facies types and structural combinations known from the Viking Graben have their counterparts in East Greenland where they can be studied in extensive exposures. East Greenland thus provided a large-scale case study comparable to the Viking Graben, as well as many small-scale facies case studies comparable to individual fields. Stratigraphically the resemblance between the Mesozoic sequence of the two areas is striking and a common stratigraphic scheme could easily be used.

While the East Greenland basin thus functions as a good model for the northern North Sea basin, its role in the ongoing and future exploration of the Norwegian shelf will be of a more direct nature. The maximum width of the Mesozoic seaway between Greenland and Norway was about $500 \mathrm{~km}$, and the distance between the present coast lines was only about $300-400 \mathrm{~km}$ (fig. 1). Geological studies and petroleum exploration in East Greenland will thus have immediate applicability to the Norwegian shelf north of $62^{\circ} \mathrm{N}$. If discoveries are made in East Greenland they may have considerable implications for the Norwegian shelf. This is particularly the case with the Permian sequence, which is the main target in East Greenland, but which is deeply buried under the Jurassic fault block fields of the northern North Sea.

\section{Geological investigations, mineral and petroleum exploration history of East Greenland}

East Greenland has a long history of geological exploration, but a more systematic approach was first introduced in the long series of expeditions led and organized by the late Lauge Koch. The results of these expeditions are synthesized by Haller (1971). Most of Koch's expeditions worked in the areas north of $72^{\circ} \mathrm{N}$ (fig. 3), and the central part of Jameson Land which contains the main Mesozoic basin was essentially terra incognita when Koch's expeditions stopped in 1958. Only the Rhaetian, Lower to Middle Jurassic and lowermost Cretaceous of southernmost coastal areas were known in some detail (Aldinger, 1935; Rosenkrantz, 1929, 1930) while the Middle Jurassic of northern Jameson Land had received initial studies (Callomon, 1961). Lead-zinc mineralisation was, however, found in the 


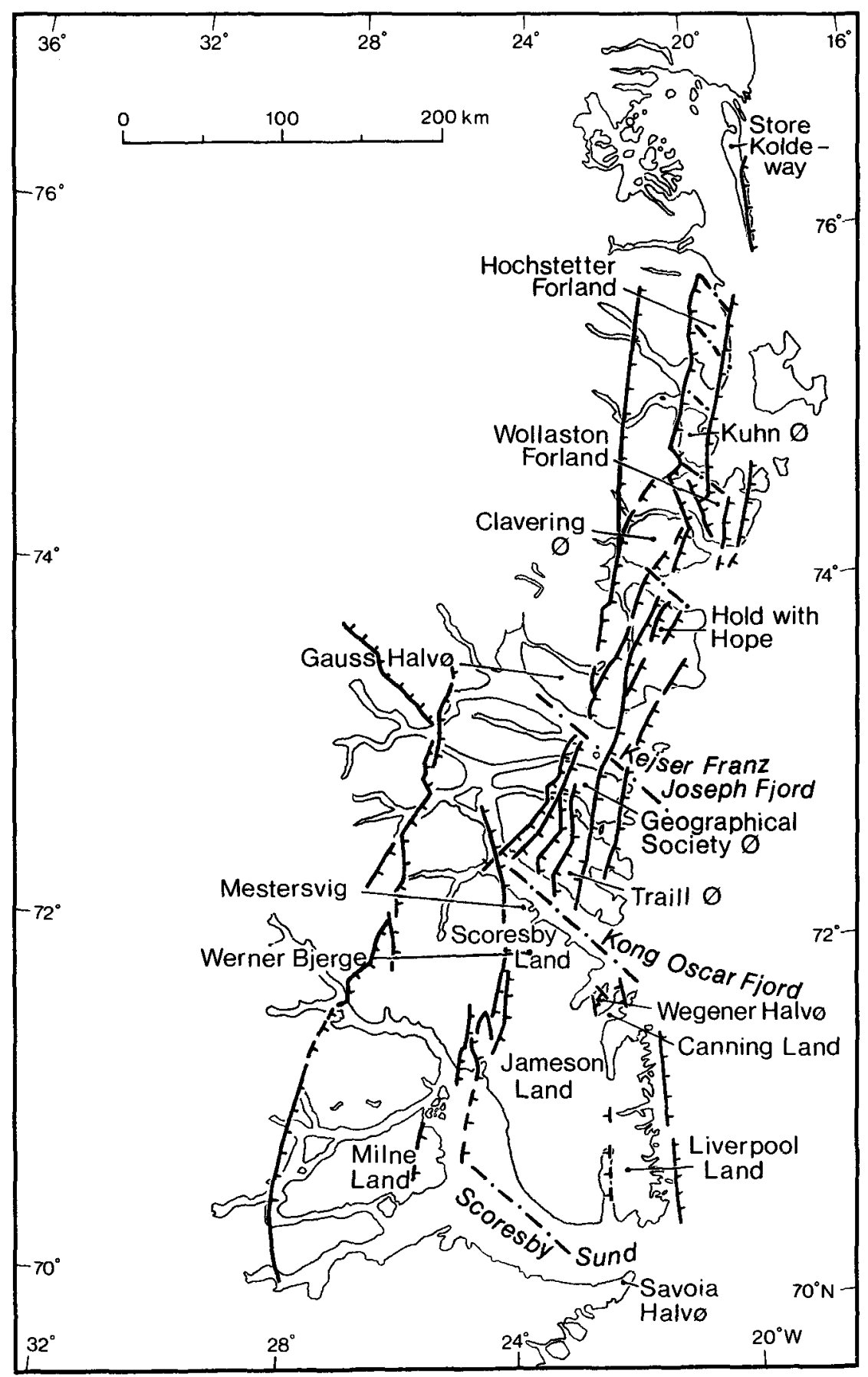

Fig. 3. Map showing main Late Palaeozoic and Mesozoic faults between latitude $70^{\circ}$ and $77^{\circ}$ in East Greenland. Based on Haller (1971), Koch \& Haller (1971), GGU maps, and own data. 
Mestersvig area in 1948 during Koch's expeditions, and a molybdenum occurrence was discovered a few years later (1953) in the Werner Bjerge (fig. 3).

Nordisk Mineselskab A/S was formed in 1952 on the basis of these discoveries. The mining company was granted a 50 year concession in 1952, which covers a land area of approximately $70000 \mathrm{~km}^{2}$ between $70^{\circ} \mathrm{N}$ and $74^{\circ} 30^{\prime} \mathrm{N}$. The concession gives the right to explore for and exploit all metals, coal, hydrocarbons and minerals in general, except cryolite and minerals containing uranium, thorium and other radioactive elements.

The lead-zinc ore was mined from 1956 until 1963, when the occurrence was exhausted. Since then several smaller mineral showings have been explored. The molybdenum occurrence in Werner Bjerge received particular attention in 1956-58 when extensive drilling was carried out, but is not considered economically viable.

In 1968 a major 5-year mapping project, which covered the whole of the Scoresby Sund region, was initiated by the Geological Survey of Greenland (GGU). During this period Jameson Land was geologically mapped by a team from the University of Copenhagen under the leadership of Tove Birkelund as part of the GGU expedition (fig. 4).

A lithostratigraphic scheme was erected for the Permian through lowermost Cretaceous sequence and a detailed ammonite biostratigraphy was worked out for the dominantly marine, post-Triassic sequence (fig. 2). This work was continued in the mid-seventies with field parties working in the Jurassic in Milne Land and central Jameson Land (Birkelund et al. 1978, 1984; Callomon \& Birkelund, 1980, 1982), and in the Triassic of Jameson Land, Scoresby Land and Traill $\varnothing$ (Clemmensen, 1980a, b). The northern part of the Mesozoic basin of East Greenland was studied with particular emphasis on the Jurassic and Lower Cretaceous sequence (Surlyk, 1977, 1978a,b, 1984).

As a result of this work the Mesozoic of East Greenland is well known in terms of lithoand biostratigraphy. Major parts of the sequence have also received considerable attention from a sedimentological point of view.

In the early seventies Nordisk Mineselskab investigated the possibilities of petroleum exploration within the 1952 concession area on a joint venture basis with Atlantic Richfield Company (ARCO). ARCO was to provide the necessary know-how and capital and Nordisk Mineselskab the concession rights. ARCO was the main shareholder in Nordisk Mineselskab, with a holding of approximately $35 \%$ of the share capital. Preliminary exploration activities of the two companies in 1971 and 1972 were discontinued at an early stage because the Ministry for Greenland considered the planned type of cooperation and financing unacceptable within the framework of the 1952 concession.

In 1969 a committee had been established to plan future concessions for oil and gas in Greenland. The work of the committee led to development of the concessional system which was valid for the petroleum exploration activities offshore West Greenland in the years 1975-1978.

In 1981 ARCO and Nordisk Mineselskab submitted an application for a petroleum exploration concession in an area covering Jameson Land and Scoresby Land to the Ministry for Greenland. This application has since formed the basis for further negotiations concerning petroleum exploration in the Jameson Land region.

During the period of negotiations ARCO - Nordisk Mineselskab carried out geophysical, geological and technical investigations in Jameson Land under a non-exclusive exploration permit in 1982 and 1983. The oil section of GGU had expeditions to the area in the same two years. The purpose of these expeditions was to provide the necessary background informa- 


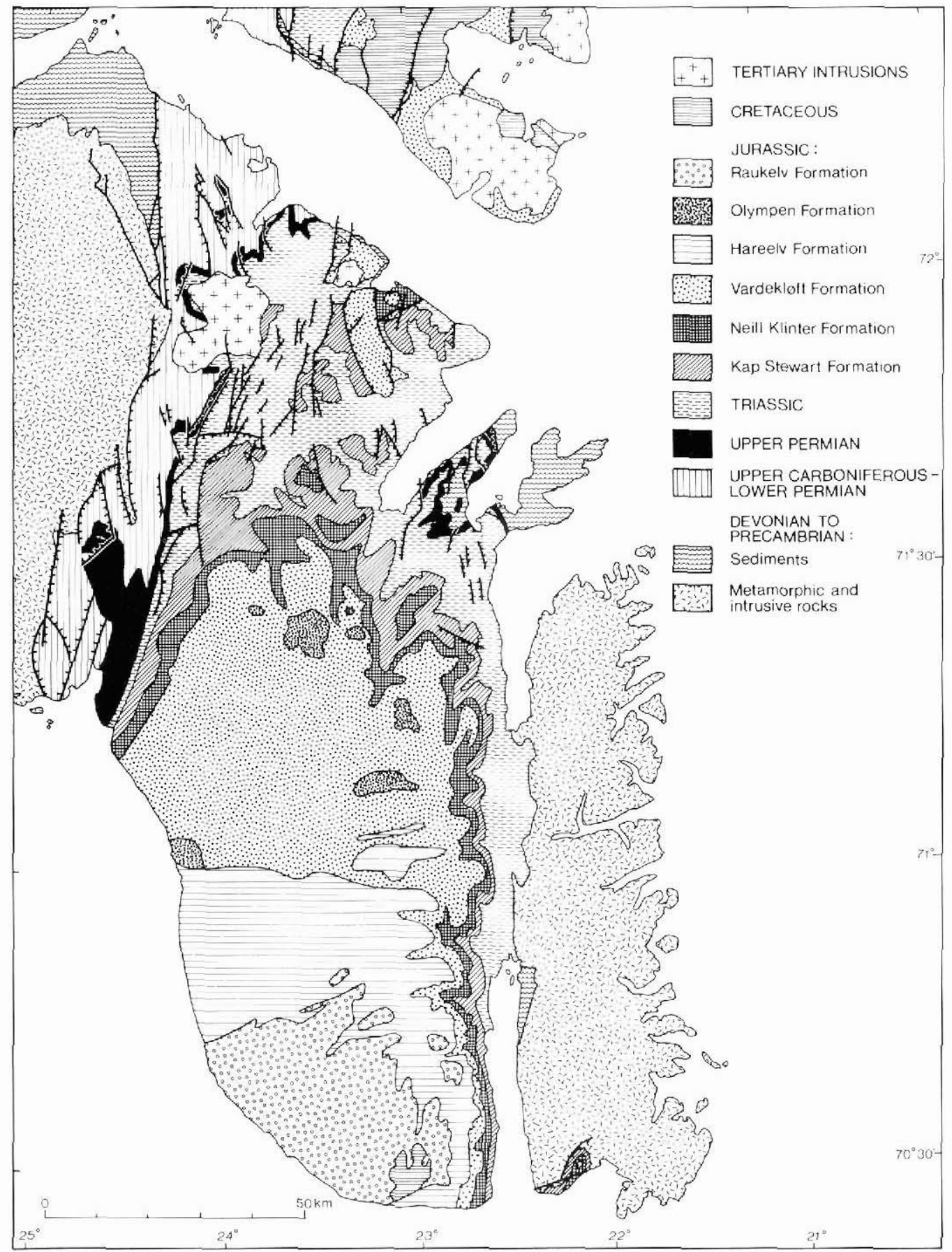

Fig. 4. Geological map of Jameson Land. Simplified after GGU maps, Koch \& Haller (1971) and Surlyk et al. (1973). 


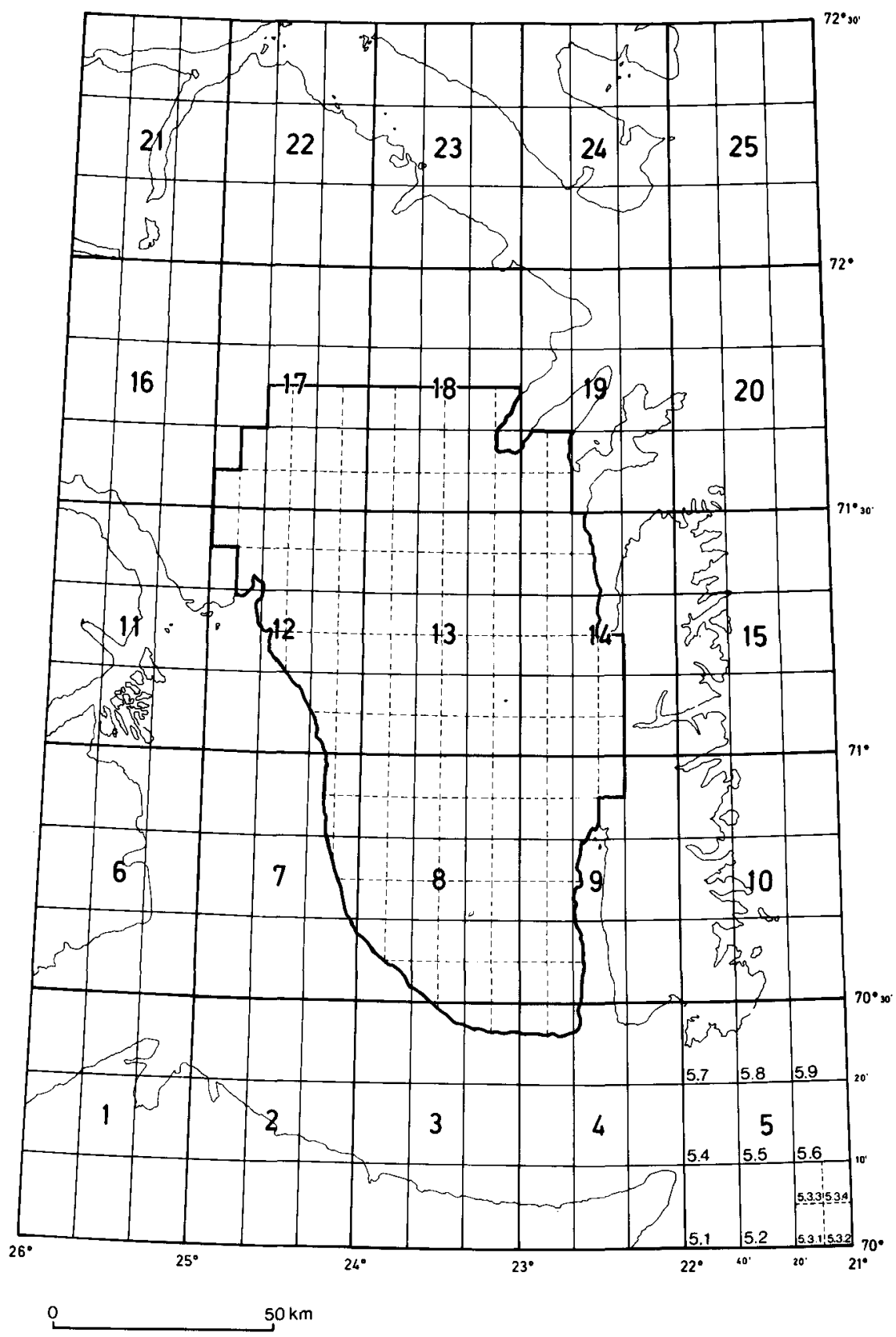

Fig. 5. Map showing the concession area of the ARCO Group and the block system defined for central East Greenland. The system forms the basis for relinquishments of the concession area on Jameson Land and covers possible future exploration areas. The identification system for the block hierarcy is shown in block 5. (Mineral Resources Administration, Ministry for Greenland, 1984). 


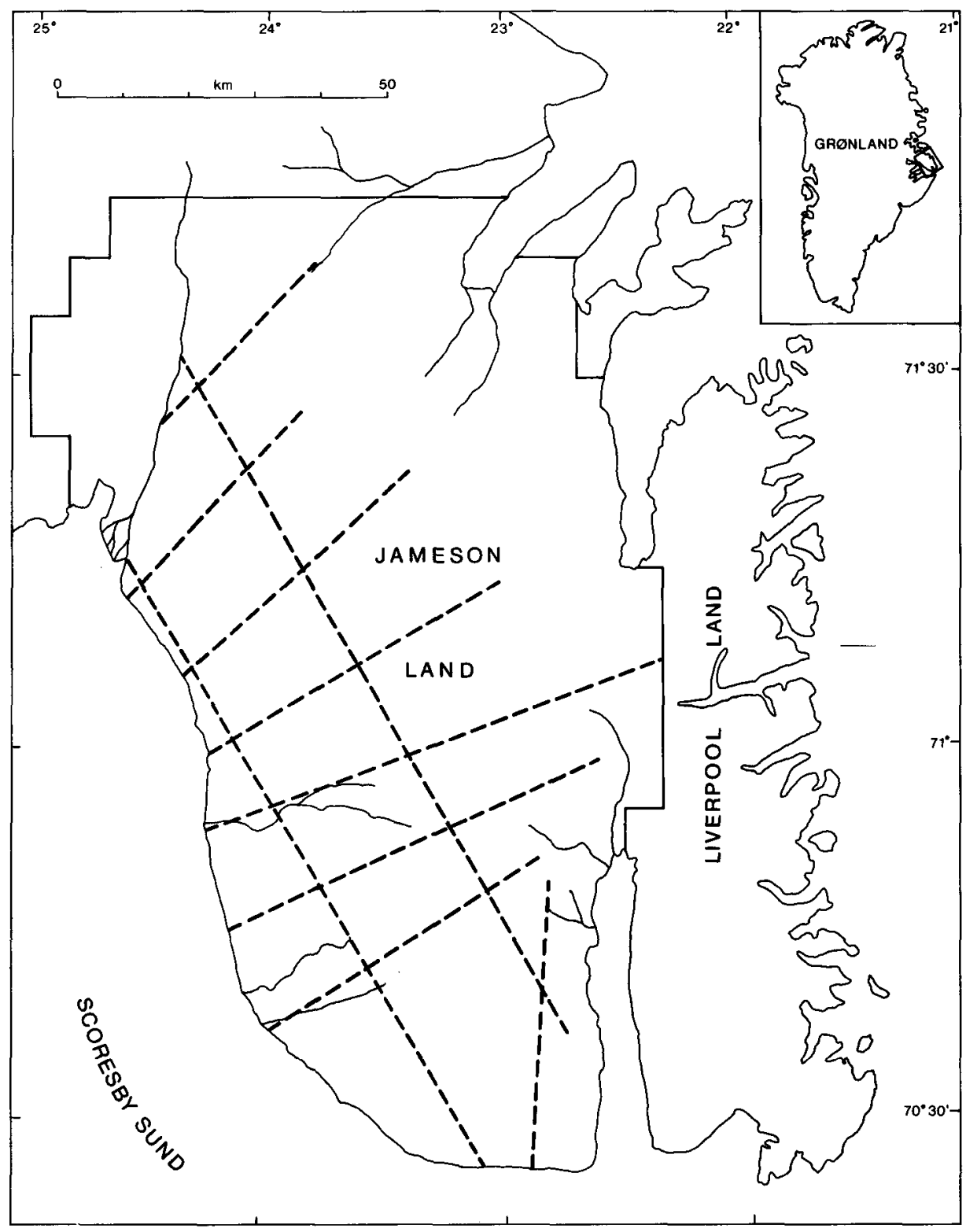

Fig. 6. Map of Jameson Land with the concession area of the ARCO Group and the basic net for $600 \mathrm{~km}$ seismic survey (Mineral Resources Administration, Ministry for Greenland, 1984). 
tion to undertake a petroleum geological evaluation of the area. Special emphasis was placed on the Upper Permian sequence which was considered the main exploration target. Possible source and reservoir rocks were sampled from the Permian as well as from the Mesozoic sequences (Surlyk, 1983; Surlyk et al., 1984a,b).

During 1984 ARCO - Nordisk Mineselskab and the authorities reached agreement on the content of the concession in terms of concession area, relinquishment scheme, working commitments, taxes and general economy. A concession was signed by both parts on 6th December, 1984 and field operations were initiated in November 1985.

The concession provides the concessionaires with the right to hydrocarbon exploration in an area of approximately $9800 \mathrm{~km}^{2}$ onshore Jameson Land for 12 years from 1st January, 1985 (fig. 5). The concessionaires may surrender the concession after 6,8 or 10 years. The normal relinquishment procedure demands relinquishment of $25 \%$ of the original area after 8 and 10 years respectively (31st December, $1992 \& 1994$ ) and the last $50 \%$ at the end of year 12 (31st December, 1996).

During the first 6 years, the concessionaires are committed to perform at least $800 \mathrm{~km}$ of seismic survey, $600 \mathrm{~km}$ of which must lie within a basic net covering the concession area (fig. 6). Two exploratory wells must be drilled down through the Upper Permian sequence or to a depth of $3660 \mathrm{~m}$. If the concessionaires surrender the concession after 6 years, the second well may be given up without economic compensation, providing that no exploration grounds exist for its drilling.

Working commitments increase during the following 2 year periods such that after 12 years a minimum of 11 exploratory wells must have been drilled.

\section{Petroleum geology of Jameson Land}

\section{General aspects}

A major N-S trending Mesozoic sedimentary basin occurs in the coastal zone of East Greenland. It is exposed over a distance of $800 \mathrm{~km}$ from the southern tip of Jameson Land $\left(70^{\circ} 25^{\prime} \mathrm{N}\right)$ to the little known areas north of Germania Land $\left(77^{\circ} 45^{\prime} \mathrm{N}\right)$. The width of the exposed parts of the basin decreases northwards from $150 \mathrm{~km}$ in the Scoresby Sund region to $5 \mathrm{~km}$ in Store Koldewey.

The thickest and most complete sequence is found in Jameson Land where approximately $8 \mathrm{~km}$ of Upper Palaeozoic and Mesozoic sediments are thought to occur in the central part of the basin (fig. 2). The nature of the substratum is not known, but outliers in Wegener Halvø and Canning Land suggest the presence of a thick, weakly metamorphosed sequence of Late Precambrian - Early Palaeozoic sedimentary rocks of the Caledonian mountain belt overlain by non-metamorphic Devonian clastics (Haller, 1971; Caby, 1976). From a petroleum exploration point of view, only the Upper Palaeozoic - Mesozoic part of the basin fill is of interest and the Lower Permian is usually considered as 'economic basement'. The Jurassic is nonprospective in most areas in onshore East Greenland because it forms the topographic surface. By contrast the Upper Permian must be considered a promising target as it contains good potential source rocks, possible reservoir rocks and is moderately deeply buried. 


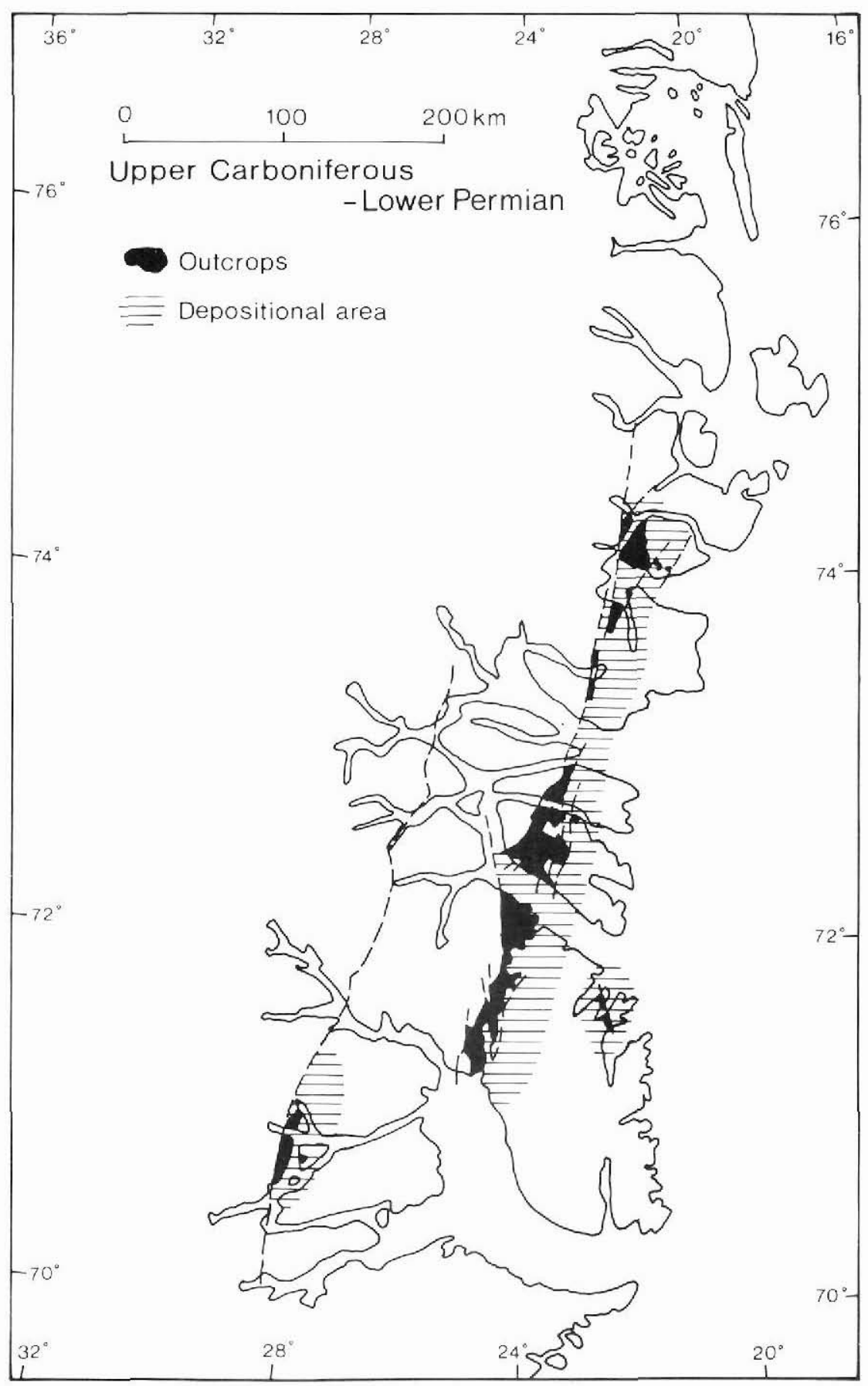

Fig. 7. Map showing the Lower Permian outerop and assumed suberop areas in East Greenland. The areas north of Jameson Land possibly also include Carboniferous rocks. The main synsedimentary fault lines are indicated. 


\section{Source rocks}

The oldest recognised potential source rocks are of Early Permian and perhaps latest Carboniferous age (figs $2 \& 7$ ). They occur as mainly 1-2 $\mathrm{m}$ thick, laterally extensive shales alternating with several metres thick, well cemented dominantly fine-grained sandstones in cyclically developed fluvial and lacustrine sequences. The shales have a high content of organic carbon (Total organic carbon (TOC) $=10-20 \%$ ), consisting mainly of lipid-rich type I kerogen of algal origin. They are particularly well exposed on the south coast of Traill $\emptyset$ where they are still thermally immature. Further south in Jameson Land the shales are mainly of back-swamp origin with organic matter of terrestrial origin. They are immature to mature along the western basin margin and become highly mature towards the east, approaching the central parts of the basin.

The main potential onshore source rock is a thick black shale sequence of Late Permian age partly equivalent to the 'Posidonia shale' of earlier authors (Maync, 1942; Birkelund \& Perch-Nielsen, 1976) (figs 2, 8-9). The content of organic matter in the shales varies, but shows a general upwards increase to a TOC of $2-5 \%$ in the upper part, which is rich in liptinite associated with varying amounts of vitrinite and inertinite. Optical and chemical studies indicate that a part of the shale sequence is a good source rock for oil. The shale is immature to weakly mature along the western basin margin, but reaches post-mature conditions on Wegener Halvø (Surlyk et al., 1984b).

The Middle Triassic Gråklint Beds of the Gipsdalen Formation are composed of grey, fossiliferous, sandy calcarenite and dark grey to black limestone (Clemmensen, 1980a,b). They have a high content of organic matter (TOC up to $4 \%$ ) and have the characteristics of a mature source rock for oil at localities south of Wegener Halvø (Surlyk et al., 1984b). Their thickness and lateral extent is, however, fairly small.

The mainly fluvial, sandy, Kap Stewart Formation of Rhaetian-Hettangian age contains thick sequences of black laminated mudstone in northern Jameson Land. The formation is intruded by thick Tertiary dolerite sills and reliable source rock data have not yet been obtained. The sand-rich parts of the formation contain coal-beds which may have some potential as a source rock for gas. This is particularly the case if the individual coal beds are more thickly developed in the basin centre than at the eastern basin margin, where they only reach a thickness of $0.5 \mathrm{~m}$.

Contemporaneous strata from the Trænabanken area on the Norwegian shelf are dominated by coal, and the net coal thickness in some wells exceeds $100 \mathrm{~m}$ (Larsen \& Skarpnes, 1984).

This Lower Jurassic coal bearing unit is considered the main source for the recent gas and gas-condensate finds in the Haltenbanken area (Throndsen et al., 1984; Pittion \& Gouadain, 1984).

A laterally consistent $100 \mathrm{~m}$ thick shale unit, the Sortehat Member, of presumed Bajocian age, also has some source rock potential (figs $2 \& 10$ ). It is oil prone in the lower part, gas prone in the upper part, has a TOC of up to $3.5 \%$ and is immature to slightly mature along the eastern basin margin.

The Oxfordian-Kimmeridgian Hareelv Formation and its lateral equivalents the Bernbjerg Formation (areas north of Kong Oscar Fjord) and Kap Leslie Formation (Milne Land) (figs $2 \& 10$ ) are the best potential source rocks for oil in East Greenland if the shelf areas are included. The formations are, however, fully exposed in most onshore areas where they 


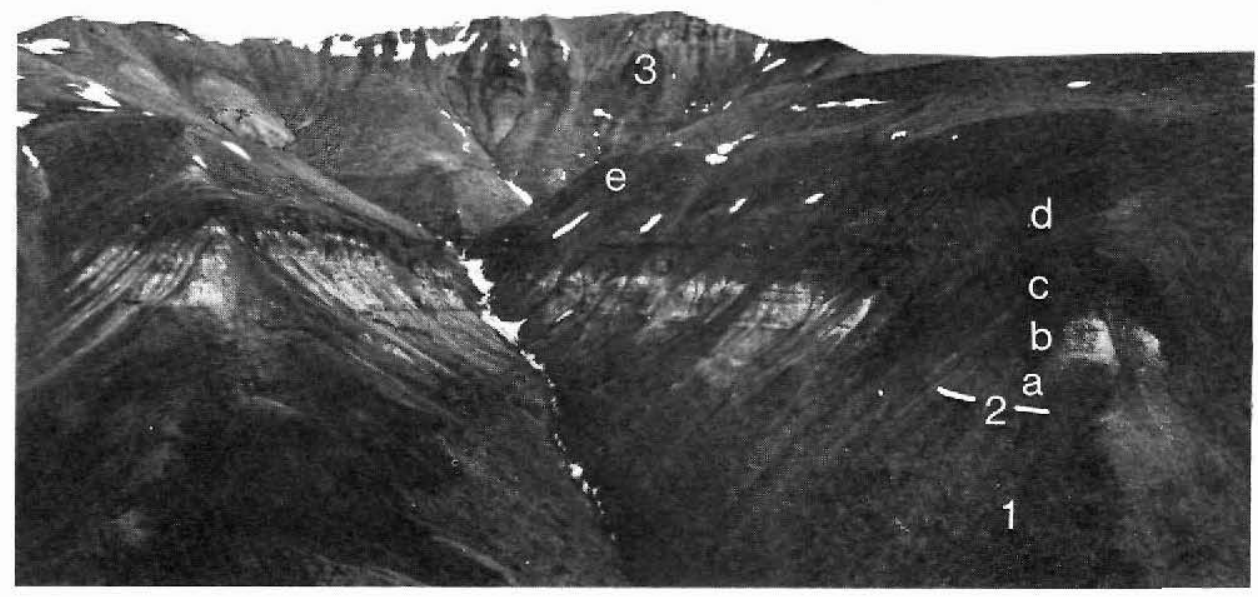

Fig. 8. The Lower Permian to Lower Triassic sequence at the east side of Schuchert Dal. 1: Lower Permian alternating shales and sandstones dipping westwards. 2: Mid-Permian peneplain followed by Upper Permian, a: basal conglomerate, b: gypsum, c: limestone with basalt sills, d: black bituminous shale, and e: shale with sandstone. 3: Lower Triassic shale and sandstone.

thus are without any interest for exploration. The formations are dominated by dark shale, like their North European equivalent the Kimmeridge Clay, and the relatively deep-water Hareelv Formation in addition contains thickly developed channel sandstone bodies. The formations are characterized by high contents of organic carbon. The Kimmeridgian part in particular is a rich source rock for oil. The formations vary in thickness from 200 to $500 \mathrm{~m}$. The organic matter of the Hareelv Formation is dominated by marine, liptinitic, unstructured material, especially in the Kimmeridgian part. Terrestrial material is well represented throughout the formation but slightly dominates in the Oxfordian part. The formation is therefore an excellent source rock for both oil and gas. The content of organic matter is highest, but variable, in the lower part (TOC $=6-12 \%)$ in contrast to the uniform content in the upper part (TOC $=5-7 \%$ ).

The Jurassic shales are immature in central Jameson Land, and immature to mature in southern Jameson Land. A small area in south-west Jameson Land is post-mature.

A thick sequence of Upper Cretaceous black shale occurs in Traill $\varnothing$ and Geographical Society $\varnothing$, north of Jameson Land, but has not yet been adequately studied.

It can thus be concluded that a relatively large number of potential hydrocarbon source rocks occur in Jameson Land and adjacent areas of East Greenland. However, only the Lower Permian lacustrine shales, the Upper Permian marine shales, and the Middle Triassic dark, marine limestones appear to be buried sufficiently deeply to be included in the evaluation of the petroleum potential of Jameson Land. Jurassic shales should, however, also be considered in the more mature southern Jameson Land. 


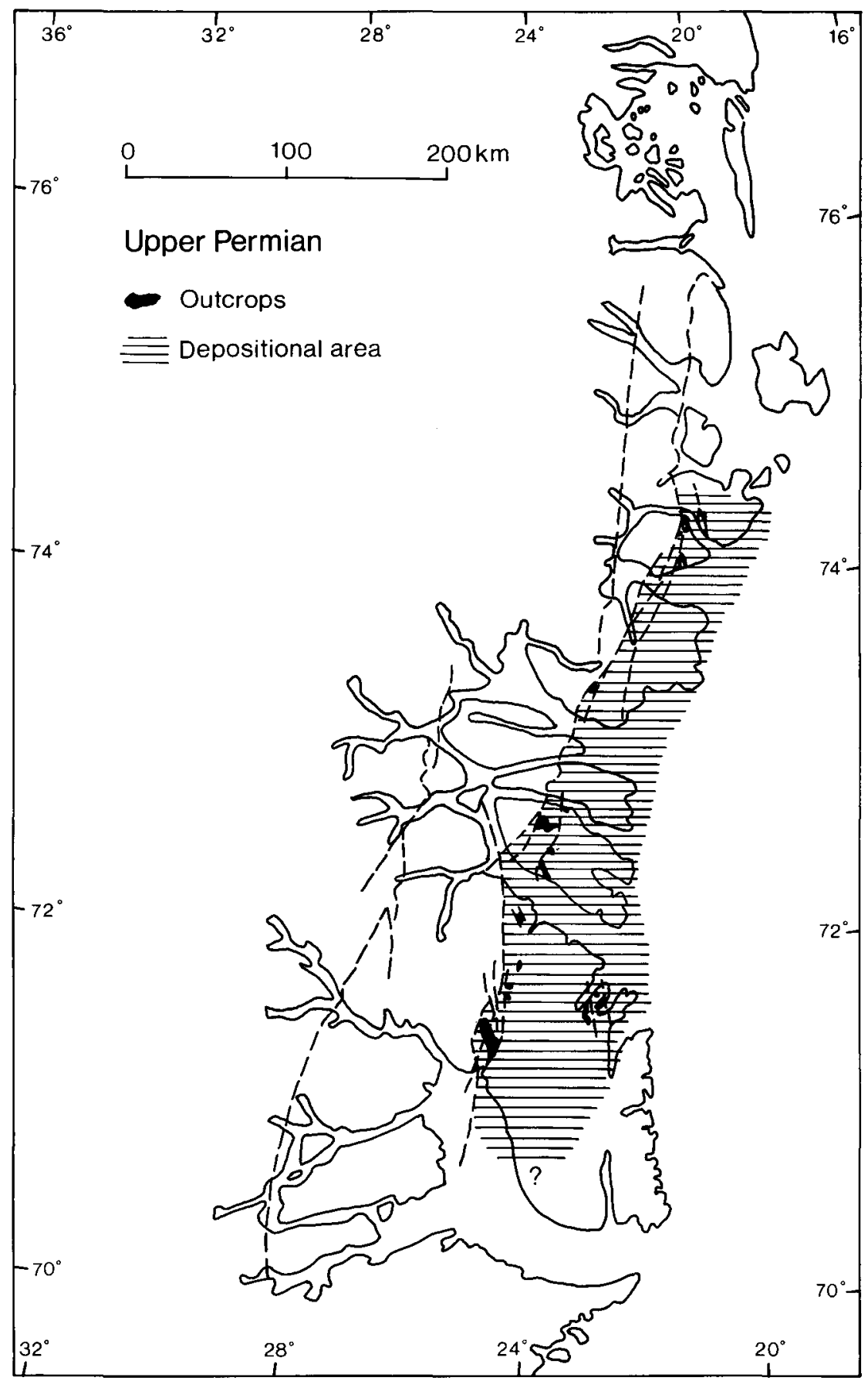

Fig. 9. Map showing the Upper Permian outcrop and assumed subcrop areas in East Greenland. The main synsedimentary faults are indicated. 


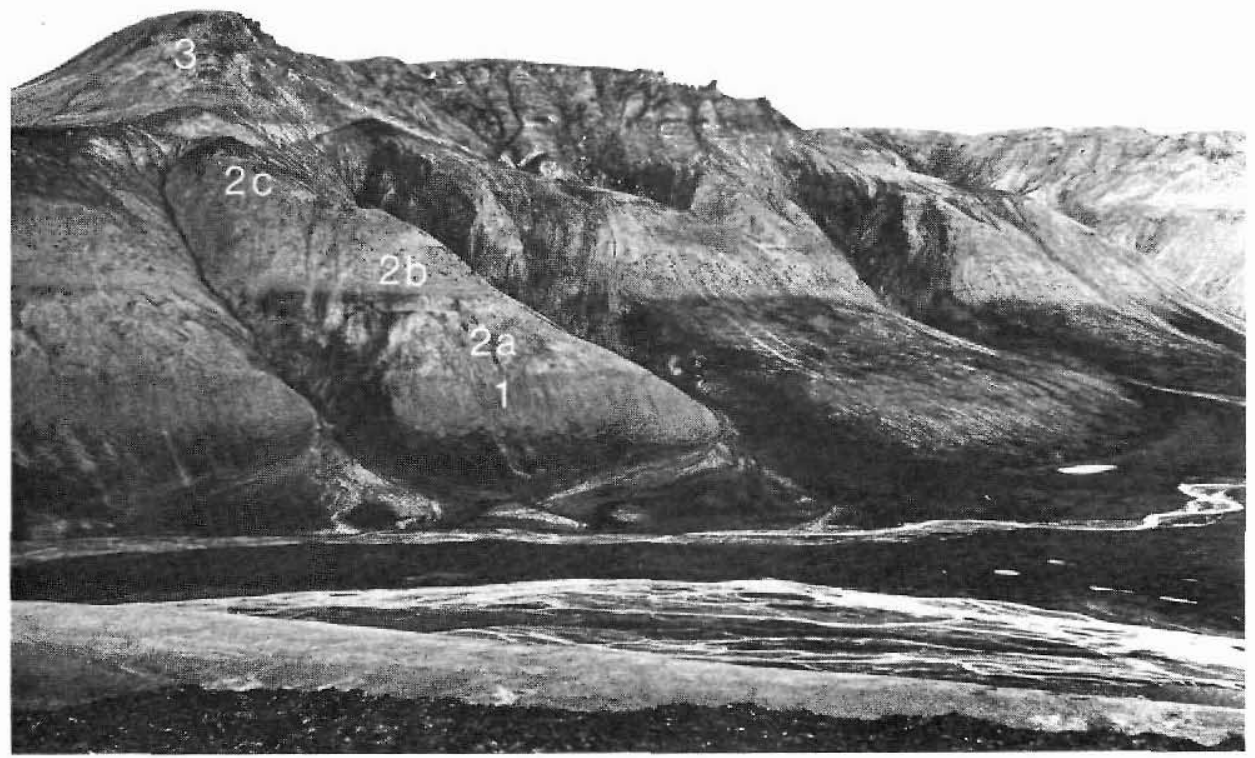

Fig. 10. The Jurassic sequence at Ugleelv, east Jameson Land. 1: Neill Klinter Formation followed by 2: Vardekløft Formation which includes, a: Sortehat Member, b: Pelion Member and c: Fossilbjerget Member. 3: the Hareelv Formation forms the upper part of the slopes and the plateau behind the ridges.

The offshore areas north of Scoresby Sund contain pre-drift sequences of Mesozoic and older age (Larsen, 1984). Most lithostratigraphic units known from the onshore areas have wide lateral distribution and can be easily matched with sequences on the Norwegian shelf (see e.g. Jacobsen \& van Veen, 1984; Karlsson, 1984). It can thus be predicted that the potential onshore Mesozoic source rocks extend into the present-day offshore areas.

\section{Reservoir rocks}

While Jameson Land contains several promising source rocks the problems concerning the occurrence of reservoir rocks appear to be more serious. The Upper Permian contains platform carbonate sequences more than $100 \mathrm{~m}$ thick which often show reef-like developments (figs $2 \& 11$ ). The carbonates seem mainly to occur over structural highs and along basin margins. Subsurface occurrences of major limestone units are, therefore, to be expected in central, and probably also southern, Jameson Land. The limestones have not yet been systematically studied for porosity and permeability. Marked Late Permian sea-level changes have, however, caused erosion, karstification and formation of collapse breccias in several carbonate areas. These processes may have resulted in improved reservoir character of the carbonate sequences.

Thick bodies of coarse uppermost Permian and Lower Triassic fan-delta sandstones or aeolian and braided river sandstones which are exposed in the western outcrop belt seem to have some reservoir potential. Otherwise the Triassic sediments are either tight mudstones 


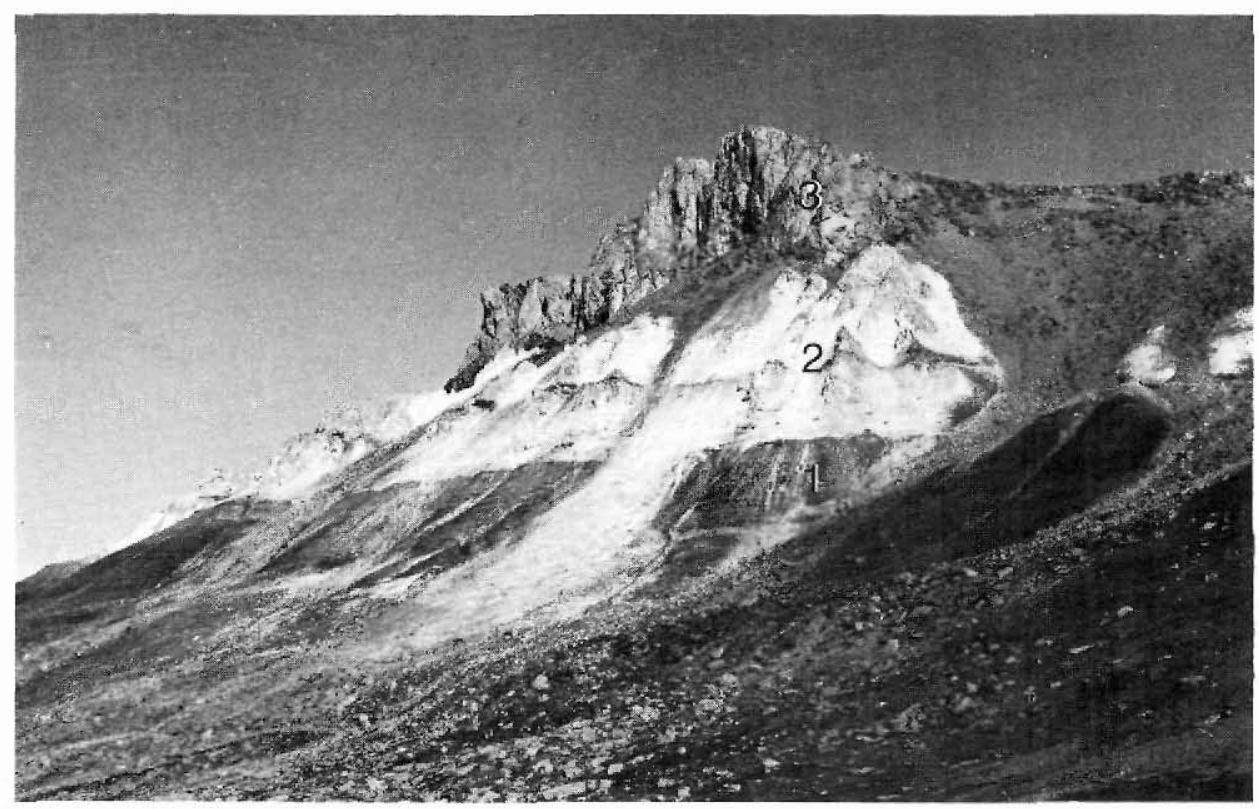

Fig.11. The Upper Permian sequence in Revdal west of Schuchert Dal. 1: basal conglomerate, 2: gypsum, and 3: platform carbonates with build-ups.

and evaporites or petrologically highly immature sandstones and conglomerates which are very susceptible to diagenetic destruction of porosity.

The Jurassic sequence includes abundant, thick quartzose sandstones with high porosity and permeability, but they are all exposed on the surface or occur in shallow subsurface positions and the reservoir potential is therefore limited. In the offshore areas the reservoir situation is much more positive as thick sequences of Jurassic sandstones can be expected to occur at favourable depths.

The combined effect of the Middle Volgian - Ryazanian rifting and regional regression resulted in deposition of thick wedge-shaped sandstone or conglomerate units which are exposed in several onshore areas. Thus the shallow marine, sandy Raukelv Formation, which is exposed in southern Jameson Land, exhibits the best reservoir characteristics of all Mesozoic formations in East Greenland (Surlyk, 1973, 1975). The contemporary Wollaston Forland Group exposed in northern East Greenland consists of deep-water conglomerates (Surlyk, 1978a, 1984). It has been extensively used as a model for several North Sea oil fields, notably the Brae field. Comparable deposits are expected to occur offshore East Greenland on the down-thrown sides of Late Jurassic-Early Cretaceous fault blocks.

It can be concluded that the offshore areas are expected to contain thick sequences of excellent Jurassic sandstone reservoir rocks. By contrast potential reservoir rocks in the onshore area of Jameson Land seem to be restricted to Upper Permian carbonates and fandelta sandstones and Lower Triassic aeolian, fan-delta and braided river sandstones. 


\section{Cap rocks}

The onshore Upper Palaeozoic - Mesozoic sequence of East Greenland, and Jameson Land in particular, contains abundant fine-grained, tight sequences which can act as seals. Thus the Upper Permian black shales locally drape over the potential carbonate reservoir rocks. The Triassic contains a basal shale sequence, evaporites in the middle part, and several thick, tight mudstones in the upper part. The same tight formations are expected to occur in the offshore areas.

The flat lying, undeformed nature of the exposed post-Middle Triassic top strata in Jameson Land suggests that generated hydrocarbons could not have escaped along faults.

\section{Traps}

Several trap types can be expected to occur in the onshore areas. The undisturbed nature of the exposed sequence in Jameson Land conceals any evidence of deeper structures such as tilted fault blocks. There is direct evidence from the western basin margin of an important mid-Permian rifting phase with block faulting and tilting, followed by peneplanisation. Sedimentological evidence from alluvial fan sequences suggests, furthermore, the existence of an Early Triassic tectonic phase with block faulting and the formation of a $\mathrm{N}-\mathrm{S}$ oriented graben in Jameson Land (Clemmensen, 1980; Surlyk et al., 1981). The post-Early Triassic erosion, draping and infilling of a fault controlled relief may thus have resulted in structural and combination type traps.

Stratigraphic facies change traps are to be expected in the Upper Permian reef and platform carbonates and uppermost Permian and Lower Triassic fan-delta sandstones, and perhaps in thick channel sandstones in the Upper Jurassic Hareelv Formation where this is most deeply buried.

In the offshore areas the most important traps are expected to be structural and combination types formed by tilted Jurassic fault blocks partly truncated by an Early Cretaceous unconformity.

Acknowledgements. We are grateful to I. Olsen for his work as a base camp manager under the expeditions to Jameson Land in 1982 and 1983, and to J. Boserup, A. Clausen and K. Villadsen for their efforts in the shallow core drilling program. We also direct our thanks to I. Jahn-Mulliner, V. Hermansen and B. Sikker Hansen for typing and artwork. The manuscript was reviewed by A. K. Higgins.

\section{References}

Aldinger, H. 1935: Geologische Beobachtungen im oberen Jura des Scoresbysundes (Ostgrönland). Meddr Grønland 99(1), $128 \mathrm{pp}$.

Birkelund, T. \& Perch-Nielsen, K. 1976: Late Palaeozoic - Mesozoic evolution of central East Greenland. In Escher, A. \& Watt, W. S. (edit.) Geology of Greenland, 305-339. Copenhagen: Geol. Surv. Greenland. 
Birkelund, T., Callomon, J. H. \& Fürsich, F. T. 1978: The Jurassic of Milne Land, central East Greenland. Rapp. Grønlands geol. Unders. 90, 99-106.

Birkelund, T., Callomon, J. H. \& Fürsich, F. T. 1984: The stratigraphy of the Upper Jurassic and Lower Cretaceous sediments of Milne Land, central East Greenland. Bull. Grønlands geol. Unders. 147, $1-56$.

Brennand, T. P. 1984: Petroleum geology in North Sea exploration 1964-1983. In Glennie, K. W. (edit.) Introduction to the petroleum geology of the North Sea, 1-15. Blackwell Scientific Publ.

Caby, R. 1976: Tension structures related to gliding tectonics in the Caledonian superstructure of Canning Land and Wegener Halvø, central East Greenland. Rapp. Grønlands geol. Unders. 72, 1-24.

Callomon, J. H. 1961: The Jurassic system in East Greenland. In Raasch, G. O. (edit.), Geology of the Arctic 1, 258-268. Toronto, U. P.

Callomon, J. H. \& Birkelund, T. 1980: The Jurassic transgression and the mid-late Jurassic succession in Milne Land, central East Greenland. Geol. Mag. 117, 211-310.

Callomon, J. H. \& Birkelund, T. 1982: The ammonite zones of the Boreal Volgian (Upper Jurassic) in East Greenland. In Embry, A. F. \& Balkwill, H. R. (edit.) Arctic geology and geophysics. Mem. Can. Soc. Petrol. Geol. 8, 349-369.

Clemmensen, L. B. 1980a: Triassic lithostratigraphy of East Greenland between Scoresby Sund and Kejser Franz Josephs Fjord. Bull. Grønlands geol. Unders. 139, 56 pp.

Clemmensen, L. B. 1980b: Triassic rift sedimentation and palaeogeography. Bull. Grønlands geol. Unders. 136, $72 \mathrm{pp}$.

Haller, J. 1971: Geology of the East Greenland Caledonides. London, New York, Sydney, Toronto: Interscience Publishers, 413 pp.

Jacobsen, V. W. \& van Veen, P. 1984: The Triassic offshore Norway north of $62^{\circ} \mathrm{N}$. In Spencer, A. M. et al. (edit.) Petroleum geology of the North European margin, 317-327. Graham \& Trotman Ltd for the Norwegian Petroleum Society.

Karlsson, W. 1984: Sedimentology and diagenesis of Jurassic sediments offshore mid-Norway. In Spencer, A. M. et al. (edit.) Petroleum geology of the north European margin, 389-396. Graham \& Trotman Ltd for the Norwegian Petroleum Society.

Koch, L. \& Haller, J. 1971: Geological map of East Greenland $72^{\circ}-76^{\circ}$ N. Lat. Meddr Grønland 183, 26 pp.

Larsen, H. C. 1984: Geology of the East Greenland shelf. In Spencer, A. M. et al. (edit.) Petroleum geology of the north European margin, 329-339. Graham \& Trotman Ltd for the Norwegian Petroleum Society.

Larsen, R. M. \& Skarpnes, O. 1984: Regional interpretation and hydrocarbon potential of the Tranabanken area. In Spencer, A. M. et al. (edit.) Petroleum geology of the north European margin, 217236. Graham \& Trotman Ltd for the Norwegian Petroleum Society.

Maync, W. 1942: Stratigraphie und Faziesverhältnisse der oberpermischen Ablagerungen Ostgrönlands (olim 'Oberkarbon - Unterperm') zwischen Wollaston Forland und dem Kejser Franz Josephs Fjord. Meddr Grønland 115(2), 1-128.

Mineral Resources Administration, Ministry for Greenland 1984: Unofficial translation. Draft. Concession to explore for and exploit hydrocarbons in an area of Jameson Land in East Greenland, 52 pp.

Pittion, J. L. \& Gouadain, J. 1984: Maturation studies of the Jurassic 'Coal Unit' in three wells of the Haltenbanken area (Norway). Symposium organic geochemistry in exploration of the Norwegian shelf, 22-24 October 1984. Stavanger: Norsk Petroleumsforening, abstract.

Perch-Nielsen, K., Birkenmajer, K, Birkelund, T. \& Aellen, M. 1974: Revision of Triassic stratigraphy of the Scoresby Land and Jameson Land Region, East Greenland. Bull. Grønlands geol. Unders. 109, $51 \mathrm{pp}$.

Rosenkrantz, A. 1929: Preliminary account of the geology of the Scoresby Sound district. Meddr Grønland 37(2), 135-154.

Rosenkrantz, A. 1930: Summary of investigations of younger Palaeozoic and Mesozoic strata along the coast of Greenland in 1929. Meddr Grønland 74(14), 347-364. 
Surlyk, F. 1973: The Jurassic - Cretaceous boundary in Jameson Land, East Greenland. In Casey, R. \& Rawson, P. F. (edit.) The Boreal Lower Cretaceous. Geol. J. Spec. Iss. 5, 81-100.

Surlyk, F. 1975: Block faulting and associated marine sedimentation at the Jurassic - Cretaceous boundary, East Greenland. NPF - Jurassic Northern North Sea Symposium 7, 1-31.

Surlyk, F. 1977: Stratigraphy, tectonics and palaeogeography of the Jurassic sediments of the areas north of Kong Oscars Fjord, East Greenland. Bull. Grønlands geol. Unders. 123, $56 \mathrm{pp}$.

Surlyk, F. 1978a: Submarine fan sedimentation along fault scarps on tilted fault blocks (Jurassic - Cretaceous boundary, East Greenland). Bull. Grønlands geol. Unders. 128, 108 pp.

Surlyk, F. 1978b: Jurassic basin evolution of East Greenland. Nature 274, 130-133.

Surlyk, F. 1983: Source rock sampling, stratigraphical and sedimentological studies in the Upper Palaeozoic of the Jameson Land basin, East Greenland. Rapp. Grønlands geol. Unders. 115, 88-93.

Surlyk, F. 1984: Fan-delta to submarine fan conglomerates of the Volgian - Valanginian Wollaston Forland Group, East Greenland. In Koster, E. H. \& Steel, R. J. (edit.) Sedimentology of gravel and conglomerates. Mem. Can.Soc.Petrol. Geol. 10, 359-382.

Surlyk, F., Callomon, J. H., Bromley, R. G. \& Birkelund, T. 1973: The stratigraphy of the Jurassic Lower Cretaceous sediments of Jameson Land and Scoresby Land, East Greenland. Bull. Grønlands geol. Unders. 105, 1-76.

Surlyk, F., Clemmensen, L. B. \& Larsen, H. C. 1981: Post-Paleozoic evolution of the East Greenland continental margin. Mem. Can. Soc. Petrol. Geol. 7, 611-645.

Surlyk, F., Hurst, J. M., Marcussen, C., Piasecki, S., Rolle, F., Scholle, P. A., Stemmerik, L. \& Thomsen, E. 1984a: Oil geological studies in the Jameson Land basin, East Greenland. Rapp. Grønlands geol. Unders. 120, 85-90.

Surlyk, F., Piasecki, S., Rolle, F., Stemmerik, L., Thomsen, E. \& Wrang, P. 1984b: The Permian basin of East Greenland. In Spencer, A. M. et al. (edit.) Petroleum geology of the north European margin, 303-315. Graham \& Trotman Ltd for the Norwegian Petroleum Society.

Throndsen, T., Elvsborg, A. \& Hagevang, T. 1984: Origin of the Haltenbanken gas condensate discoveries. Symposium organic geochemistry in exploration of the Norwegian shelf, 22-24 October 1984. Stavanger: Norsk Petroleumsforening, abstract. 